\title{
ERROR ANALYSIS ON VOICING SOUNDS UTTERED BY ENGLISH DEPARTMENT STUDENTS AT STATE ISLAMIC INSTITUTE OF MADURA
}

\author{
Abdul Wafi ${ }^{1}$ \\ ${ }^{1}$ English Teaching Learning Program, Tarbiyah Faculty, Institut Agama Islam Negeri Madura, \\ Pamekasan 69371, Indonesia \\ (wafizain1234@gmail.com) \\ Rinta Ratnawati ${ }^{2}$ \\ 2English Teaching Learning Program, Tarbiyah Faculty, Institut Agama Islam Negeri Madura, \\ Pamekasan 69371, Indonesia \\ (rintataufiq@gmail.com) \\ Ansharul Fuqaha'3 \\ ${ }^{3}$ Islamic Business Management Program, Department of Islamic Business and Economics, Institut \\ Kariman Wirayudha Sumenep, \\ (ansharulofficial@gmail.com)
}

\begin{abstract}
English pronunciation is unique and said as badly spelled. The difference between what has been written with what they should pronounce is a vital factor. This study is aimed at finding out the error in pronouncing the voiced and voiceless sounds made by the students of Tadris Bahasa Inggris IAIN Madura. The study uses a descriptive design with qualitative data. The population is second-semester students who are taking pronunciation subject in $C$ class with 32 students. The result shows that of 10 minimal pairs tested to the students, the percentage students who can pronounce the words correctly is that $37 \%$ students for 1 st minimal pairs, $81 \%$ for 2 nd one, $31 \%$ for 3 rd one, $50 \%$ for 4th one, for 5th one 31\% in the word 'laugh' and $87 \%$ in the word 'love', $21 \%$ for 6 th one, for the 7 th one $6 \%$ in the word 'measure' and 18\% in the word 'sure', for the 8 th one $9 \%$ in the word 'stronger' and $84 \%$ in the word 'stranger', for the 9th one $21 \%$ in the word 'eyes' and 93\% in the word 'rats' and 31\% in the word 'buses', for the 10th one $31 \%$ in the word 'robbed' and 31\% in the word 'washed' and 12\% in the word 'needed'. It can be concluded that most of the students are not aware of voicing sounds in English pronunciation. It is suggested that giving drill of minimal pairs and introducing them to places and manners of articulation might be able to improve their awareness to produce correct pronunciation.
\end{abstract}

Keywords: Voicing Sounds; Minimal Pair; Places and Manners of Articulation

First Received:

(June 06, 2020)
Final Proof Received:

(September 03, 2020)

\section{INTRODUCTION}

Pronunciation is taken as the most significant aspect in spoken English (Karlina, Rahman, \& Chowdhury, 2020), although it is still neglected in the majority of the classroom (Alhaddad, Kusumah, Sabandar, \& Dahlan, 2015; Atli \& Bergil, 2012; Cahyono \& Widiati, 2015). It is one of the skills of speaking in a foreign language that has its difficulties is correct pronunciation (Gowhary, Azizifar, \& Rezaei, 2016). It is because if a 
speaker makes mistakes in pronunciation, the hearers will get misunderstanding with what he means. As being often experienced by the writers in the classroom teaching, they encountered some students mispronounce several words enabling them to get misunderstanding with what the students mean. For instance, the word 'beard' and 'bird'; one of the students responded a regular question 'what do you like and dislike from me particularly in the way I teach?' knowing that the teacher has beard on his chin, she responded 'I like your long beard, sir' which she pronounced 'beard' as /b3:(r)d/. The pronunciation /b3:(r)d/ is 'bird' where 'beard' should be pronounced '/bi:ə(r)d/' and it results that of her pronunciation '/b3:(r)d/ could be meant in the Indonesian language as "Saya suka burung panjangmu, Pak" instead of "Saya suka jenggot anda yang panjang, Pak". 'Long bird' and 'long beard' are two different things. Even, 'long bird' is containing taboo by its definition which is 'long bird' may mean the sex of man by its connotation.

English pronunciation is unique and said as badly spelled (Wafi, 2011). It is because what is written is somehow really different from what is to be pronounced as in the word 'breathe, breath', mustache, enough, bourgeois, Illinois, Charlotte, through, judge', and so forth. Making mistake in one sound within syllables could change its meaning as in the word 'food \& foot', 'pig \& pick', 'rope \& robe', 'close-which is as a verb and as an adjective, 'massage $\&$ message', 'advice $\&$ advise', 'doze \& those', 'shoe \& chew' and so on. For its unique spelling system, the error in pronunciation may happen frequently.

Regarding the error, Weinberger (Kurniawan, 2016: 158) stated that the error occurs in the absence of certain sounds in the native language, and as a result, the learners replace them with similar sounds. The error occurs because of the differences between the source language and target language (Demirezen \& Kot, 2016). Indonesian students, where English as a foreign language and Indonesian as their native language, usually make errors in pronouncing the English words. They pronounce the words mostly by leaving out certain sounds and replacing them with similar sounds for example in the word 'pleasure'. Mostly students pronounce it as /plesə/ where its correct pronunciation is /plezə(r)/. They make the sound /3/ abstained and then they replace it with the sound /s/.

Of its difficult pronunciation, Jones (1975: 2) states that the students of spoken English or any other spoken language are faced at the outset with difficulties of five kinds in the matter of pronunciation. They are as follows: (a) He must learn to recognize readily and with certainly the various speech-sound occurring in the language, when he hears them pronounced, he must moreover learn to remember the acoustic qualities. (b) He must learn to make the foreign sounds which his organs of speech. (c) He must learn to use those sounds in their proper places in connected speech. (d) He must learn the proper usage in the matter of 'sounds attributes' or 'prosodies' as they often called (especially length, stress, and voice-pitch). (e) He must learn to contact sounds, i.e. to join each sound of sequence on to the next, and pronounce the complete sequence rapidly and without stumbling." 
Ample previous studies on the error in pronunciation have been conducted. Sembiring \& Fiber (2016: 40) researched analyzing the pronunciation errors made by the fourth-semester students of the English Education study program at UNIKA. Their research is on vowel, diphthong, and consonant sounds. It was found that the students' error is because of the unfamiliarity with the words, lack of practicing English words, and understanding the pronunciation subject. In specific, Kurniawan, (2016: 159-160) researched error analysis in dental fricative consonants $/ \theta /$ and $/ ð /$ pronounced by the students of the English Education study program faculty of teacher training and education Sriwijaya University. It was found that most students made errors in pronouncing the voiceless dental fricative sound $/ \theta /$ by substituting it with voiceless alveolar stop /t/or with voiced alveolar stop /d/. For the voiced dental fricative /ð/, mostly the students pronounced it as /d/which sounds / $d /$ belongs to a voiced alveolar stop.

English has its standard pronunciation and English learners particularly English as a Foreign language must be able to use the standard one as their effort to sound native-like and to be taken as the English speaker of widely understood pronunciation which is termed as Received pronunciation (RP). Jones, (1972: 4) classified the people who made use of clearly intelligible to all ordinary people as 'Good Speech' and 'Bad speech' which is difficult for most people to understand. It is therefore the EFL students are required to learn and master the standard pronunciation.

Concerning the importance of using standard pronunciation, IAIN Madura provides the subject of 'Pronunciation' to train the students of Tadris Bahasa Inggris (TBI) to be able to use standard English pronunciation. In this research, the writer conducts classroom research to find out some errors made by the students in pronouncing 'voicing sound-voiced \& voiceless sounds'. There are 4 classes in pronunciation subject namely A, B, C, and D. The total amount of students is 145 students. However, the researcher focuses on one class namely $\mathrm{C}$ class to be the sample of the research due to its most active and dominant class. There are 34 students in C class; however, 2 of them never attend the class meeting due to unknown-information. So, active students are 32 students.

The researcher is interested in researching error analysis on voicing sounds because it is observed that his students have less awareness of distinguishing and pronouncing some English speech sounds particularly voiced sounds and voiceless sounds such as /d $/$ and $/ \mathrm{t} /, / \delta /$, and $/ \theta /, / 3 /$ and $/ \delta /$. Therefore, this study is conducted under the title "Error Analysis on Voicing Sounds Uttered by English Department Students at State Islamic Institute of Madura" as an effort to meet the real percentage of students who are pronouncing the words given correctly and incorrectly and what factors lie behind their error making in pronouncing those words by focusing on articulating voicing sounds. By knowing so, it can be beneficial input on how to help learners in having a better correct pronunciation. 


\section{LITERATURE REVIEW}

\section{Voicing Sounds}

The sounds in English cover pure vowels, diphthongs, and consonants. Among those sounds are voicing sounds which are either voiced sounds and voiceless sounds. (O'Grady, William, John Archibald, and Mark Aronoff., Archibald, \& Aronoff, 1989: 16) makes a clear distinction between both. Voiced sounds are when the vocal folds are brought close together, but not tightly closed, air passing between them causes them to vibrate. While voiceless sounds are when the vocal folds are pulled apart and air passes directly through the glottis. To determine whether a sound is voiced or voiceless is by lightly touching the fingers to the larynx as it is produced. Vowel sounds are included in voiced sound while consonant sounds are included in voiced and voiceless sounds. The sounds are described in a table below:

Table 1.

Table of Voiced and Voiceless Consonant Sounds

\begin{tabular}{|c|c|c|c|}
\hline \multicolumn{2}{|c|}{ Voiced Sounds } & \multicolumn{2}{|c|}{ Voiceless Sounds } \\
\hline /b/ & : Bib & $/ \mathrm{p} /$ & : Peep \\
\hline /g/ & : bag & $/ \mathrm{k} /$ & : back \\
\hline /d/ & : died & $/ t /$ & : tight \\
\hline /z/ & : zoo & /s/ & : so \\
\hline$/ 3 /$ & : pleasure & $/ \int /$ & : bush \\
\hline / ð/ & : breathe & $/ \theta /$ & : breath \\
\hline /ds/ & : judge & $/ \mathrm{t} /$ & : church \\
\hline /v/ & : of & /f/ & : off \\
\hline$/ \mathrm{m} /$ & : mom & $/ \mathrm{h} /$ & : home \\
\hline$/ \mathrm{n} /$ & : nine & & \\
\hline$/ \mathrm{n} /$ & : sing & & \\
\hline$/ \mathrm{l} /$ & : lull & & \\
\hline$/ \mathrm{r} /$ & : roar & & \\
\hline$/ \mathrm{w} /$ & : wow & & \\
\hline$/ \mathrm{s} /$ & : yes & & \\
\hline
\end{tabular}

\section{Place of Articulation}

One of the ways to describe consonant sounds is by describing their place of articulation. (O'Grady, William, John Archibald, and Mark Aronoff. et al., 1989: 19-20), (Jones, 1972: 25) and (Sembiring \& Fiber, 2016: 42-44) elaborate on the places of articulating the sounds as follow:

a. Bilabial: sounds articulated by involving the lower lip and upper lip. The sounds are $/ \mathrm{b} /, / \mathrm{b} /, / \mathrm{m} /$.

b. Labio-dental: sounds articulated by involving the lower lip and upper teeth. The sounds are /f/, /v/.

c. Dental: sounds produced with the tongue tip placed against or near the upper teeth. The sounds are $/ \delta /, / \theta /$. 
d. Alveolar: sounds produced by the tip or blade of the tongue againts the teeth-ridge. The sounds are /t/, /d/, /s/, /z/, /l/, /n/.

e. Alveopalatal or palato alveolar: sounds which have alveolar articulation together with a simultaneous raising of the main body of the tongue towards the roof of the mouth (palate). The sounds are $/ \mathrm{f} /, / 3 /, / \mathrm{t} /, / \mathrm{d} /$.

f. Palatal: sounds articulated by the front of the tongue against the hard palate. The sounds are $/ \mathrm{j} /$.

g. Velar: sounds articulated by the back of the tongue against the soft palate. The sounds are $/ \mathrm{k} /, / \mathrm{g} /, / \mathrm{n}$.

h. Labio-velar: sounds articulated by having the tongue raised near the velum and the lips are rounded at the same time. The sound is /w/.

i. Retroflex: sounds produced by curling the tip of the tongue up and back towards the rear edge of the alveolar ridge. The sound is $/ \mathrm{r} /$.

j. Glottal: sounds produced in the glottis. The sound is $/ \mathrm{h} /, \mathrm{z} /$.

\section{Manner of Articulation}

Consonant sounds are also able to be described in the manner how they are articulated. (O'Grady, William, John Archibald, and Mark Aronoff. et al., 1989: 21-26) and (Jones, 1972: 25-26) and (Sembiring \& Fiber, 2016: 44-46) elaborate the manner of articulating the sounds as follow:

a. Plosive / stops: sounds formed by completely closing the air passage through the oral cavity and suddenly removing the obstacle, so that the air escapes making an explosive sound. The sounds are /p/ /b/, /t/ /d/, /k/ /g/, / $/$.

b. Fricative: sounds produced with a continuous airflow through the mouth. It is formed by a narrowing of the air passage at some point so that the air in escaping makes a kind of hissing sound. The sounds /f/ / / / $/ / \delta / / \mathrm{s} / \mathrm{z} / / \mathrm{J} / \mathrm{3} /$.

c. Affricates: sounds formed by briefly stopping the airstream completely and releasing the articulators slightly so that friction is produced. The sounds are $/ \mathrm{t} /$ and $/ \mathrm{d} /$.

d. Nasal: sounds are produced with the velum lowered and complete obstruction in the nasal cavity. The sounds are $/ \mathrm{m} /, / \mathrm{n} /, / \mathrm{y} /$.

e. Liquid or Lateral: is produced by resting the tongue on the alveolar ridge with the airstream escaping around the sides of the tongue. The sound is /l/.

\section{Minimal Pairs}

Tuan (2010: 1) states that minimal pairs bear great benefits in pronunciation teaching and learning which have long been of fruitful use. It enables the learners to be aware of distinctive speech sounds in English such as voiced and voiceless sounds. Furthermore, Nilsen (1973: 15) defined that a minimal pair consists of two words pronounced alike except for a single phonemic difference. A phoneme is the smallest unit 
of a significantly distinctive sound. The phonemic difference is responsible for radical changes in the meaning of the word, as in hat-hit or thing-sing. Consequently, errors in auditory discrimination and/or articulation of these sounds may result in misunderstanding and misinterpretations of the meaning of the word, phrase, or sentence.

Having minimal pair to be frequently drilled enables the learners to improve their pronunciation to be more intelligible. It is in line with (Hansen, 1995: 36) stating that language teachers can improve their students' pronunciation markedly drilling minimal pairs to help them improve their intelligibility. When learners compare and contrast discrete sounds in the environment presented in minimal pairs, the importance of these sounds in denoting word meaning is transferred to their mind naturally. Experience shows that pronunciation classes make students more conscious of their pronunciation and aware of how their pronunciation differs from the model offered.

\section{METHOD}

This research made use of a qualitative descriptive study design to analyze the data. The qualitative data are in the form of utterances (in words) produced by 32 students from C class as a sample out of 145 students who are majoring in Tadris Bahasa Inggris at IAIN Madura as the total population. This research was conducted by giving the students some words containing voicing sounds to read and questionnaires distribution. The list of the words containing voicing sounds (voiced \& voiceless) is prepared by the researcher and given to the students to read. While reading it, the researcher records it in a video to make it as authentic data. The questionnaire is given to each student to gain the data of their difficulties in pronouncing those words. All of the data are processed and developed by the researcher descriptively.

\section{RESULTS AND DISCUSSION}

\section{Results}

\section{a. A test is given}

The test given is in the form of words. There are 22 words in the form of minimal pairs. As it is shown below:

\section{Table 2.}

The 22 words tested to the students

\begin{tabular}{ll}
\hline 1. Robe - Rope & 6. Rice - Rise \\
2. Back - Bag & 7. Measure - Sure \\
3. Breathe - Breath & 8. Stronger - Stranger \\
4. Hurt - Heard & 9. Eyes - Rats - Buses \\
5. Laugh - Love & 10. Robbed - Washed - Needed \\
\hline
\end{tabular}

There are 10 pairs of minimal pairs. The first pair is 'robe and rope'. Of 32 students, it was found that 12 students (37\%) pronounced the words (robe and rope) as /roub/ and 
/rəup/ while 3 students (9\%) pronounce them with the same pronunciation as /ru:p/, 3 students (9\%) pronounced them as /rob/ and 7 students (21\%) pronounced them similarly as /roup/. Meanwhile, 7 students ( 21\%) were found to pronounce them similarly as /roub/.

The second minimal pair is 'back and bag'. It was found that 26 students (81\%) pronounced the sound /bæk/ and /bæg/ while 4 students (12\%) pronounced 'back' as /bæ...k/ with a long vowel and 'bag' as /bæg/ with short vowel /æ/. 2 students (6\%) pronounced 'back' as /beik/ and 'bag' as /beig/.

The third minimal pair is 'breathe and breath'. From the students' recordings, it was found that 10 students (31\%) pronounced the two words as /bri: $\delta /$ and /bre $\Theta /$ while 17 students (53\%) pronounced them with the same pronounciation as /bri: $\Theta / .1$ student (3\%) pronounced the words with same pronunciation as /bret/ and 1 student (3\%) pronounced them as /breie/. 2 students (6\%) pronounced 'breathe' as /bre $\theta /$ and 'breath' as /brs:t/ while 1 student (3\%) pronounced 'breathe' as /bret/ and 'breath' as /brit/.

The fourth words are 'hurt and heard'; it was found that 16 students (50\%) pronounced the two words as /h3:t/ and /h3:d/ while 11 students (34\%) pronounced 'hurt' as /ha:t/ and 'heard' as /hiəd/. 1 student (3\%) pronounced them with same pronounciation as /h3:t/ while 2 students (6\%) pronounced 'heard' as /ha:rd/ and 2 students $(6 \%)$ pronounced 'heard' as /hi:d/.

The fifth words are 'laugh and love'; from the recordings, it was found that 10 students (31\%) pronounced the word 'laugh' as /la:f/. Meanwhile, 18 students (56\%) pronounced it as /laugh/, 2 students (6\%) pronounced it as /laut/, 1 student (3\%) pronounced it as /la:gh/ and 1 student (3\%) articulated it as /l3:f/. For the word 'love', it was found that 28 students (87\%) pronounced it as $/ \mathrm{l} \Lambda \mathrm{v} /, 2$ students $(6 \%)$ pronounced it as /lov/ and 2 students (6\%) pronounced it as /ləv/.

The sixth words are 'rice' and 'rise'; it was found that 7 students (21\%) pronounced the two words as /rais/ and /raiz/ while 11 students (34\%) pronounced them with the same pronounciation as /rais/, 3 students (9\%) pronounced them as /raiz/ and 4 students (12\%) pronounced them as /ri:s/. 5 students (15\%) pronounced 'rice' as /reis/ and 'rise' as /reis/. Meanwhile, 2 students (6\%) pronounced 'rice' as /raiz/ and 'rice' as /rais/.

The seventh words are 'measure' and 'sure'; it was found that 27 (84\%) students pronounced the word 'measure' as /mi:sə/, 1 student (3\%) pronounced it as /mju:sə/, another 1 student (3\%) pronounced it as /miasur/ and 1 student (3\%) pronounced it as /misiə/. Meanwhile, 2 students (6\%) pronounced it as /mezə(r)/. For the word 'sure', it was found that 6 students (18\%) pronounced it as /Juər/, 8 students $(25 \%)$ pronounced it as /s3:r/, 4 students (12\%) pronounced it as /suə/, 3 students (9\%) pronounced it as /su:(r)/ and 1 student (3\%) pronounced it as /siuə/. 
The eighth words are 'stronger' and 'stranger'; it was found that 3 students (9\%) pronounced the word 'stronger' as /strongə(r)/, 22 students (68\%) pronounced it as /strondzə(r)/, 1 student (3\%) pronounced it as /strond3/, 4 students (12\%) pronounced it as /stronə(r)/ and 2 students (6\%) pronounced it as /stro: $\bigvee$. For the word 'stranger', it was found that 27 students (84\%) pronounced it as /streindzə(r)/, 2 students (6\%) pronounced it as /strein/, 2 students (6\%) pronounced it as /strenə/ and 1 student (3\%) pronounced it as /strengə/.

The ninth words are 'eyes', 'rats' and 'buses'; for the word 'eyes', it was found that 7 students (21\%) pronounced it as /aiz/, 10 students (31\%) pronounced it as /ais/ while 10 students (31\%) pronounced it as /eis/, 1 student (3\%) pronounced it as /iəs/, 1 student (3\%) pronounced it /ijes/, 2 students (6\%) pronounced it as /aes/, 1 student (3\%) pronounced it as /I:s/. For the word 'rats', it was found that 30 students (93\%) pronounced it as /ræts/ while 2 students (6\%) pronounced it as /rets/. For the word 'buses', it was found that 10 students (31\%) pronounced it as /b $\Lambda$ siz/, 10 students (31\%) pronounced it as /bjusis/, 2 students (6\%) pronounced it as /bis/, 1 student (3\%) pronounced it as /bius/, 1 student (3\%) pronounced it as /bus/, 2 students (6\%) pronounced it as /bəs/, 1 student (3\%) pronounced it as /bjusəs/, 1 student (3\%) pronounced it as /b3:s/, 2 students (6\%) pronounced it as /b $\Lambda \mathrm{s} /, 1$ student (3\%) pronounced it as /bus/ and 1 student (3\%) pronounced it as /bisəs/.

The tenth words are 'robbed', washed' and 'needed'; for the word 'robbed', it was found that 10 students (31\%) pronounced it as /robd/, 8 students (25\%) pronounced it as /robəd/ and 14 students (43\%) pronounced it as /ru:bd/. For the word 'washed', it was found that 10 students (31\%) pronounced it as /wo:ft/, 8 students (25\%) pronounced it as /weist/, 6 students (18\%) pronounced it as /weIJ/, 8 students (25\%) pronounced it as /wo:fit/. For the word 'needed', it was found that 4 students (12\%) pronounced it as /ni:did/, 4 students (12\%) pronounced it as /ni:dəd/, 4 students (12\%) pronounced it as /ned/ and 20 students (62\%) pronounced it as /ni:d/.

\section{b. Questionnaires}

From the questionnaire given containing 10 Yes/No questions, it was found that of 32 students, 31 students (96\%) find difficulty in reading the text given which contains some words of minimal pairs while 1 student (3\%) finds it easy to read. Being questioned about whether the students' mother tongue interferes with their difficulty in pronouncing the text given, it is found that 25 students (78\%) answer 'no' while 7 students (21\%) agree that mother-tongue interferes their ability to their pronunciation.

The third question is about the influence of 'personal style of students, known as idiolect, in their accuracy to pronounce the words given; it is found that 13 students (40\%) agree with while 19 students (59\%) disagree that idiolect influences their accuracy to their pronunciation. 
The fourth is asking the students on their familiarity to voicing sounds; 25 students (78\%) are familiar with it while 7 students $(21 \%)$ are not. Related to the fourth question, the fifth question is asking them whether the students know the difference between voiced sound and voiceless sound; 28 students (87\%) know it and the rest 4 students (12\%) do not know the difference between both. However, when it comes to the sixth question asking whether its difference is in the vibrating and not vibrating the vocal cord, all of the students agree with it.

The seventh and the eighth questions are about sounds belong to voiced and sounds belong to voiceless; of 32 students, 30 students (93\%) recognize the sounds belong to voiced sounds and 2 of them (6\%) do not recognize them. Related to voiceless sounds, 26 students (81\%) recognize them and 6 students (18\%) do not recognize them.

The ninth question is about the importance of introducing the places and the manners of articulation to the students as the way to improve their pronunciation mastery; all of the students agree that introducing the places and manners of articulation to the students for improving their pronunciation mastery based on standard English. Meanwhile, the tenth question is about giving 'minimal pairs drill' to the students as a way of making them aware of pronouncing English speech sounds correct; 30 students (93\%) are in line with the giving of minimal pair drill while the rest 2 students (6\%) abstain.

\section{Discussion}

Rogers (2000: 192) states that linguists agreed that consonants are described in three different ways, those are place, manner, and voicing. As like the sound $/ \mathrm{z} /$ and $/ \mathrm{J} /$, if they are described in term of their place of articulation, the sound /z/ is included into alveolar where the place of the sound is in the tip or blade of the tongue against the teethridge, while $/ \delta /$ is included into alveo palatal where the place of the sound is in alveolar articulation together with a simultaneous raising of the main body of the tongue towards the roof of the mouth (palate).

While in terms of the manner of articulation, the sounds $/ z /$ and $/ J /$ are similarly included in Fricative in how the sounds are produced with a continuous airflow through the mouth. It is formed by a narrowing of the air passage at some point so that the air in escaping makes a kind of hissing sound. Furthermore, in terms of voicing sound, the sound $/ z /$ is included as voiced sound and $/ \mathrm{J} /$ is included as voiceless sound. To distinguish both of them is Voiced sounds are when the vocal folds are brought close together, but not tightly closed, air passing between them causes them to vibrate. While, voiceless sounds are when the vocal folds are pulled apart and air passes directly through the glottis (O'Grady, 1989: 16).

In discussing the findings, the first minimal pair 'robe' and 'rope' is testing the different sound of $/ b /$ and $/ p /$ where $/ b /$ is a voiced sound and $/ p /$ is a voiceless sound. From the result, it might be stated that only 12 students (37\%) who pronounce the word 
'robe' and 'rope' correctly as they pronounce 'robe' as /roub/ and 'rope' as /roup/ with a clear distinction between sound /b/ and /p/.

In the second minimal pairs 'bag' and 'back' are testing the different sound of /g/ as voiced velar stops consonant and $/ \mathrm{k} /$ as voiceless velar stops consonant. From the findings, it resulted that 26 students (81\%) pronounce the words correctly as /bæg/ and /bæk/. Meanwhile, 4 students (12\%) mispronounced the word 'black' as /blæ...k/ with long vowel /æ/ where it must be short because its neighboring sound is $/ \mathrm{k} /$ as a voiceless consonant. The length of vowel sound before a voiceless consonant should be shorter than the vowel sound before a voiced consonant such as in the word 'bag'.

The third minimal pair 'breathe' and 'breath' is testing the distinctive sound of $/ \delta /$ as a voiced dental fricative consonant and $/ \theta /$ as a voiceless dental fricative consonant. From the findings, it could be stated that there were only 10 students (31\%) who can pronounce the two words correctly-breathe as $/ \mathrm{bri}: \delta /$ and breath as $/ \mathrm{bre} \Theta /$. They are able to distinguish between sound $/ \delta /$ and $/ \theta /$. The sound $/ \delta /$ is articulated by vibrating the vocal cord where its place of articulation is at the tongue tip placed against or near the upper teeth and being produced by narrowing the air passage at some point so that the air in escaping makes a kind of hissing sound. Meanwhile, the sound $/ \theta /$ is articulated without vibrating the vocal cord where its place and manner of articulation are the same as the sound $/ \delta /$. Meanwhile, other students are having a problem with the two sounds $/ \theta /$ and $/ \delta /$ that they pronounce $/ \mathrm{t} /$ instead of $/ \theta /$ and $/ \delta /$. They pronounce breathe as /brit/ and breath as /bret/. The sound / $t /$ is different from $/ \theta /$ and $/ \delta /$ in terms of voicing and place as well as the manner of articulation. Sound $/ t /$ is included in voiceless alveolar stops consonant sound.

The fourth minimal pairs 'hurt' and 'heard' is testing the different sound between $/ t /$ and $/ d /$. The sound $/ t /$ is included in voiceless alveolar stops the consonant sound and the sound /d/ in included in voiced alveolar stops consonant sound. The difference between the two sounds lies in the voicing where $/ t /$ is voiceless being pronounced without vibrating the vocal cord and / $d$ / is pronounced by vibrating the vocal cord. From the findings, it resulted that 16 students (50\%) pronounced the two words (hurt and heard) correctly. While some students found problem in distinguishing / $\mathrm{t} /$ and /d/ and some others found problem in vowel sounds such as 'hurt' pronounced as /ha:t/ and 'heard' as /hiəd/ and /ha:rd/.

The fifth minimal pairs, 'laugh' and 'love', is testing the sound /f/ and /v/ where both sounds are included in labio-dental fricative consonant sound. However, the /f/ sound is voiceless, and / $\mathrm{v} /$ is a voiced sound. From the findings, it resulted that there were 10 students (31\%) pronounced the word 'laugh' correctly as /la:f/ while 18 students pronounced it as /laugh/ for they only read textually based on the letters. As it is seen from the result of the questionnaire, it seemed that they were interfered with by their Indonesian language to pronounce what is written whereas it is different from English 
which is said to be badly spelled. In English spelling '..gh' could be pronounced as /..f/ such as in the word 'enough' /insf/. Meanwhile, 2 students (6\%) pronounced /..t 5 / instead of /..f/. It was different between sound $/ \mathrm{t} /$ and /f/ where sound $\mathrm{t} / \mathrm{is}$ a voiceless alveopalatal affricate consonant sound. For the word 'love', there were 28 students (87\%) pronounced the word 'love' correctly as $/ \mathrm{l} \Lambda \mathrm{v} /$. While the rest ones encountered problems in the vowel sounds as /lov/ and /ləv/.

The next minimal pairs, 'rice' and 'rise', is testing the distinctive sound between /s/ and $/ \mathrm{z} /$. Both of the two sounds are included in alveolar fricative consonant sound however the difference is in voicing which is /s/ sound is voiceless and /z/ sound is voiced. From the findings, it resulted that only 7 students $(21 \%)$ were able to pronounce the two words correctly which was the word 'rice' pronounced as /rais/ and 'rise' as /raiz/. Meanwhile, 11 students (34\%) were not able to distinguish both sounds. As a result, they pronounced the word 'rice' and 'rise' similarly as /rais/ while 3 students (9\%) pronounced them similarly as /raiz/. Meanwhile, 2 students (6\%) pronounced the words in reverse 'rice' as /raiz/ and 'rise' as /rais/.

The seventh minimal pairs ,'measure' and 'sure', is testing the different sound between $/ 3 /$ and $/ \delta /$. Both sounds are included in alveo-palatal fricative consonant sound with the distinction in terms of voicing; /3/ is a voiced sound and $/ \delta /$ is a voiceless sound. From the findings, it resulted that only 2 students $(6 \%)$ were able to pronounce the word 'measure' correctly as /'mezə(r)/, while the rest students pronounced sound /s/ instead of /3/ such as /mi:sə/ or /mju:sə/ or /miasur/ and /misiə/. It seemed that the sound /3/ was not really familiar to them that they preferred to pronounce it as $/ \mathrm{s} /$ as what it was seen on the spelling 'measure'. Sound /s/ was different from /3/ in terms of their places and manner of articulation. The sound /s/ was included in a voiceless alveolar fricative consonant sound and the sound /3/ was included in voiced alveo-palatal fricative consonant sound. For the word 'sure', there were only 6 students (18\%) able to pronounce it correctly as / Juər/ while most of them were not. It seemed that the sound / $/$ / was not familiar to them as well as /3/. They preferred to pronounce as what was spelled 'sure' with /s/.

The eighth minimal pairs, 'stronger' and 'stranger', is testing the different sound between $/ \mathrm{n} /$ and $/ \mathrm{d} /$. Basically, the two sounds were really distinctive in terms of points of articulation and manners of articulation even though both of them were similar to voiced sound. The sound $/ \mathrm{h} /$ is included in a voiced velar nasal consonant sound and the sound / $d 3 /$ is included in voiced alveopalatal affricates consonant sound. The researcher was interested in testing the two words 'stronger and stranger' because the two words were the words with additional bound morpheme 'er' from the root 'strong' and 'strange'. It was believed that it would be confusing for the students to pronounce both words and it was obvious that based on the findings, it resulted that there were only 3 students (9\%) 
who were able to pronounce the word 'stronger' correctly as /strongə(r)/ while the rest students pronounced it incorrectly.

Meanwhile, in the word 'stranger', most of the students (27 students) (84\%) were able to pronounce it correctly as /streindzə(r)/ while the rest students pronounced it incorrectly based on IPA. What was interesting was that there were 22 students (68\%) pronounced the word 'stronger' as /strondzə(r)/. It seemed that most of the students thought that pronouncing the word 'stronger' was similar to 'stranger' by using the sound / $\mathrm{d} /$ before the morpheme 'er'.

The ninth minimal pairs, 'eyes-rats-buses', is testing the different sound /s/ and /z/. It was quite similar to the sixth minimal pair 'rice and rise'; however, the ninth minimal pair focused on pronouncing the additional morpheme 's/es' in plural forms. Wafi (2018) elaborated that there were three different ways to pronounce the additional morpheme 's/es' in regular plural forms of some nouns; they were /z/, /s/ and /rz/ (p.70). It was /z/ when it was ended by sounds $/ \mathrm{b}, \mathrm{v}, \mathrm{m}, \mathrm{n}, \mathrm{l}, \mathrm{r}, \mathrm{j}, \delta, \mathrm{g}$ and vowels sounds/ such as 'eye' /ai/ + s became 'eyes' /aiz/. It was pronounced with /s/ after sounds /p,t,k,f/ such as 'rat' /ræt/ + s became 'rats' /ræts/. It was pronounced with /rz/ after sounds /s,z, 3, J, d3, t / such as 'bus' /b $\Lambda$ s/ + es became 'buses' /b $\Lambda$ siz/.

From the findings, it resulted that there were only 7 students (21\%) able to pronounce the word 'eyes' correctly as /aiz/ while the rest students pronounced it incorrectly. Instead of pronouncing with sound /z/ as a voiced alveolar fricative consonant sound, they pronounced it with sound $/ \mathrm{s} /$ as a voiceless alveolar fricative consonant sound. They pronounced it as /ais/, /eis/, /ijes/ and /aes/. For the word 'rats', the findings showed that 30 students (93\%) found no problem to pronounce it correctly. They pronounced it as /ræts/ and there were only 2 students (6\%) encountered problem in terms of a vowel sound that they pronounced it as /rets/. In this case, it seemed very obvious that all of the students had no difficulty to pronounce the word 'rats' in terms of the additional morpheme ' $s$ ' because it was readable as it was spelled. Meanwhile, for the word 'buses', the findings showed that there were only 10 students (31\%) able to pronounce it correctly as /bısiz/ while the rest students encountered a problem to pronounce it. Instead of pronouncing /Iz/ for the additional morpheme 'es', they pronounced it as /Is/ and /əs/ such as /bijusis/ and /bijusəs/ while the rest students did not pronounce the morpheme 'es'. They pronounced the word 'buses' as /b3:s/, /b $\Lambda$ s/ and /bus/.

The tenth minimal pair, 'robbed', washed' and 'needed' is testing different sound /d/ and $/ \mathrm{t} /$. Both of them are included in alveolar plosive consonant sound with the distinction is in the voicing; / $\mathrm{d} /$ is a voiced sound and / $\mathrm{t} /$ is a voiceless sound. However, the focus of the pair is on the additional morpheme ' $d$ /ed' in the past form of regular verbs.

Wafi (2018) elaborated that there are three different ways to pronounce the additional morpheme of 'd/ed' in the past form of regular verbs; they are /d/, /t/ and /Id/. 
It was /d/ when the morpheme ' $d$ /ed' lied after sounds /b,g,v,z,l,r,m,n.../ such as the word 'rob' /rob/ + ed became 'robbed' /robd/. It was / $\mathrm{t} /$ when the word, before being added morpheme 'd/ed', ended with sounds /p,k,f,s,t $\mathrm{f}, \ldots$.../such as in the word 'wash' /wof/ + ed became 'washed' /woft/. It was /Id/ when the morpheme 'd/ed' lied after sounds / $t$ and d/ such as in the word 'need' /ni:d/ + ed became 'needed' /ni:drd/.

From the findings, it resulted that there were only 10 students (31\%) able to pronounce the word 'robbed' correctly as /robd/. While the 14 students (43\%) encountered the problem in term of vowel sound; they pronounced it as /ru:bd/ and the rest students (8 students) (25\%) encountered the problem in term of pronouncing the additional morpheme 'ed' that was pronounced as /əd/ which should be /d/. For the word 'washed', there were only 10 students (31\%) able to pronounce it correctly as /wo:ft/, 8 students $(25 \%)$ encountered the problem in term of pronouncing the vowel sound and changing the sound / $/$ / with /s/ that they pronounced the word 'washed' as /weist/, 6 students $(18 \%)$ encountered problem of pronouncing the vowel sound and skipped to pronounce the additional morpheme 'ed' that they eventually pronounced the word 'washed' as /weif/. Meanwhile, 6 students (18\%) mispronounced the additional morpheme 'ed' as /It/ which it should be /t/ that they pronounced the word 'washed' as /wo:Sit/.

For the word 'needed', there were only 4 students (12\%) able to pronounce it correctly as / ni:did/. 4 students encountered problems in terms of pronouncing the additional morpheme 'ed' as /əd/ which should be /Id/ that they pronounced the word 'needed' as /ni:dəd/. Meanwhile, 20 students (62\%) abstained to pronounce the additional morpheme 'ed' that they finally pronounced the word 'needed' as /ni:d/ and 4 students $(12 \%)$ encountered the problem in term of pronouncing the vowel sound and abstaining the pronunciation of the morpheme that eventually they pronounced the word 'needed' as /ned/.

\section{CONCLUSION}

From the results of the study, it can be drawn several conclusions, they are (1) most of the respondents are not really aware of the voicing sounds-voiced and voiceless sounds. (2) they tend to read what is spelled. (3) they barely know and recognize the sounds of $/ 3 /$ and $/ \delta /, / d /$ and $/ \mathrm{t} /, / \delta /$ and $/ \theta /$. (4) they are not really able to distinguish the sounds between /d/ and /t/, /s/ and /z/, /b/ and /p/, /g/ and /k/, /v/ and /f/. (5) they do not really know the three ways of pronouncing the bound morpheme of 'd/ed' in the second form of regular verbs (6) they do not recognize the three ways of pronouncing the bound morpheme of 's/es' in the plural forms of the noun.

To overcome the problems, as what is resulted from the questionnaire given, the suggestions are made for the teacher or lecturer to give more opportunity to the students to get accustomed to knowing and mastering the places and manners of articulation as 
well as giving drills of minimal pairs for all of the time. For the students, it is suggested to keep learning to recognize the phonetic symbols and pronounce their sounds correctly that the students are able to check the correct pronunciation by themselves in Oxford or Cambridge dictionary. So any time they are confused with the pronunciation of certain words, they are able to fix their incorrect pronunciation by referring to those dictionaries.

\section{REFERENCES}

Alhaddad, I., Kusumah, Y. S., Sabandar, J., \& Dahlan, J. A. (2015). Enhancing Students Communication Skills through Treffinger Teaching Model. JME: Journal on Mathematics Education, 16(1), 31-39.

Atli, I., \& Bergil, A. S. (2012). The Effect of Pronunciation Instruction on Students' Overall Speaking Skills. Procedia - Social and Behavioral Sciences, 46, 3665-3671. doi: 10.1016/j.sbspro.2012.06.124.

Cahyono, B. Y., \& Widiati, U. (2015). The Teaching of EFL Listening in the Indonesian Context: The State of the Art. TEFLIN Journal, 20(2), 194-211. doi: 10.15639/teflinjournal.v20i2/194-211.

Demirezen, M., \& Kot, E. (2016). Collegial Reactions to Faulty Pronunciation of Teachers in Relation to English Language Teaching. Procedia - Social and Behavioral Sciences, 232, 471-478. doi: 10.1016/j.sbspro.2016.10.064.

Gowhary, H., Azizifar, A., \& Rezaei, S. (2016). Investigating English Vowel Reduction in Pronunciation of EFL Teachers of Schools. Procedia - Social and Behavioral Sciences, 232, 604-611. doi: 10.1016/j.sbspro.2016.10.083.

Hansen, D. (1995). A Study of the Effect of the Acculturation Model on Second Language Acquisition. In Eckman, Fred R., Jean Mileham, Rita Rutkowski Weber, Diane Highland, and Peter W. Lee. Second Language Acquisition Theory and Pedagogy. New Jersey: Lawrence Erlbaum Associates. New Jersey: Lawrence Erlbaum Associates.

Jones, D. (1972). The Pronunciation of English. Cambridge: Cambridge University Press.

Jones, D. (1975). An Outline of English Phonetics. Cambridge: Cambridge University Press.

Karlina, Y., Rahman, A., \& Chowdhury, R. (2020). Designing Phonetic Alphabet for Bahasa Indonesia (PABI) for the teaching of intelligible English pronunciation in Indonesia. Indonesian Journal of Applied Linguistics, 9(3), 724-732. doi: 10.17509/ijal.v9i3.23223.

Kurniawan, D. (2016). The Error Analysis of the Pronunciation of Dental Fricative Consonants $(/ \Theta /, / ð /)$ by the Students of English Education Study Program Faculty of Teacher Training and Education Sriwijaya University. The Journal of English Literacy Education, 3(2), 7. 157-163. doi: 10.36706/jele.v3i2.3619.

Nilsen, D. L. F. (1973). Pronunciation Contrasts in English. New York: Regents Publishing Company, Inc. New York: Regents Publishing Company, Inc.

O'Grady, William, John Archibald, and Mark Aronoff., W., Archibald, J., \& Aronoff, M. (1989). Contemporary Linguistics: An Introduction. New York: St. Martin’s Press.

Rogers, H. (2000). The Sounds of Language: An Introduction to Phonetics. London. 
Sembiring, N., \& Fiber, Y. A. (2016). An Analysis of Pronunciation errors made by the fourth-semester students of the English education study program at UNIKA. Jurnal Suluh Pendidikan. 3(1).

Tuan, L. T. (2010). Teaching English Discrete Sounds through Minimal Pairs. Journal of Language Teaching and Research. 1(5). 540-561, doi: 10.4304/jltr.1.5.540-561.

Wafi, A. (2011). Using the Think-Pair-Share Strategy to Increase Students' Active Involvement and to Improve Students' Speaking Ability at Islamic the University of Malang (Dissertation). Universitas Negeri Malang. 
Abdul Wafi, Rinta Rahmawati, \& Ansharul Fuqaha, Error Analysis on Voicing Sounds ... 